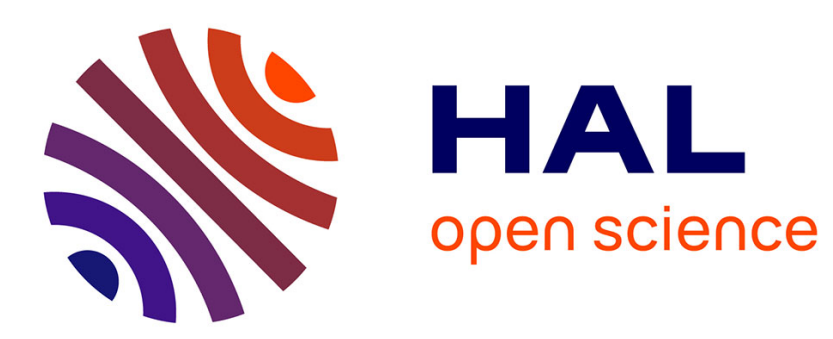

\title{
The importance of Venous Thromboembolism - a physical consequence of psychiatric treatments
}

Gerard Stansby, Simon Noble, Oliver Howes

\section{To cite this version:}

Gerard Stansby, Simon Noble, Oliver Howes. The importance of Venous Thromboembolism - a physical consequence of psychiatric treatments. International Journal of Clinical Practice, 2010, 64 (8), pp.1005. 10.1111/j.1742-1241.2010.02435.x . hal-00552662

\section{HAL Id: hal-00552662 https://hal.science/hal-00552662}

Submitted on 6 Jan 2011

HAL is a multi-disciplinary open access archive for the deposit and dissemination of scientific research documents, whether they are published or not. The documents may come from teaching and research institutions in France or abroad, or from public or private research centers.
L'archive ouverte pluridisciplinaire HAL, est destinée au dépôt et à la diffusion de documents scientifiques de niveau recherche, publiés ou non, émanant des établissements d'enseignement et de recherche français ou étrangers, des laboratoires publics ou privés. 


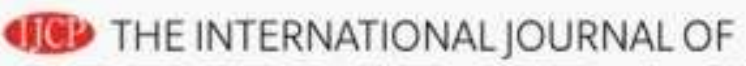 CLINICAL PRACTICE}

\section{The importance of Venous Thromboembolism - a physical consequence of psychiatric treatments}

\begin{tabular}{|c|c|}
\hline Journal: & International Journal of Clinical Practice \\
\hline Manuscript ID: & IJCP-03-10-0190.R1 \\
\hline Manuscript Type: & Editorial \\
\hline $\begin{array}{r}\text { Date Submitted by the } \\
\text { Author: }\end{array}$ & 29-Mar-2010 \\
\hline Complete List of Authors: & $\begin{array}{l}\text { Stansby, Gerard; Freeman Hospital, Vascular Surgery } \\
\text { Noble, Simon; Cardiff University, Pallitive Care } \\
\text { Howes, Oliver; Kings College London, Psychiatry }\end{array}$ \\
\hline Specialty area: & \\
\hline
\end{tabular}

\section{scholaroNE" \\ Manuscript Central}


Venous thromboembolism (VTE) is a big problem, and it is big problem that has a large iatrogenic and preventable component: it is estimated that 25,000 people in the UK die from preventable hospital-acquired venous thromboembolism (VTE) every year ${ }^{1}$. This includes patients admitted to hospital for medical care of all types and for surgery, and is many times more than deaths from methicilin resistant staphylococcus aureus infection, for example. The inconsistent use of prophylactic measures for VTE in hospital patients has also been widely reported ${ }^{2}$. However, there is a paucity of data specifically related to patients with psychiatric disorders. NICE have recently issued evidence-based guidance on VTE prevention for all adult hospital in-patients in England and Wales ${ }^{3}$. This guidance applies equally to psychiatric units and | day surgery units, although it does not specifically mention them as a separate group ${ }_{\sharp}$ At the heart of the new guidance is the requirement to assess all patients on admission and again within 24 hours ${ }^{4}$. This recommendation also forms the key element of the new Commissioning for Quality and Innovation (CQUIN) targets for Hospital Trusts in England and Wales and VTE prevention has now been declared one of two key priorities for the NHS over the coming year ${ }^{5}$.

It has been known for many years that immobility is a major potential cause of venous thromboembolism (VTE). Immobility decreases lower limb venous flow by abolishing the calf muscle pump and immobility in the sitting position is likely to be worse than lying down due the pooling effects of gravity in the lower limb veins. Likewise, endothelial perturbation from surgery or trauma also increases the risk. Other key risk factors include dehydration, cancer, increasing age and weight and a prior history of Deep Vein Thrombosis (DVT) or Pulmonary 
Embolism (PE). The U.K. Department of Health (DH) have recently developed a simple risk factor score which balances the risks of VTE against any bleeding risks for hospital patients Non- surgical patients are considered at high risk if they are expected to have ongoing reduced mobility relative to their normal state and have one or more other stated risk factors ${ }^{6}$. Of interest in psychiatry is the fact that electro-convulsive therapy and antipsychotic drugs can also increase the risk of thrombotic disorders, including VTE, the latter probably by a mechanism involving platelet activation ${ }^{7-9}$. Physical restraints themselves may increase thrombogenicity especially if the process is traumatic ${ }^{10}$. Psychiatric patients receiving physical restraint may therefore have a number of risk factors indicating an increased VTE risk, including sedation and prolonged immobility in the sitting position. The case reports of VTE and even death following physical restraint show that this is of more than just academic interest ${ }^{11-12}$. However, this risk appears to be poorly appreciated and under-researched- physical restraint is not mentioned as a specific risk | factor in the U.K. DH risk assessment tool and there is little data on the magnitude of risk in patients receiving it in the published literature

For these reasons the article by Hert et al in the current issue is very timely. This study presents data on 679 Belgian patients with schizophrenia of whom 170 had been secluded.

Pharmacological VTE prevention was used in 38\% of these secluded patients but Hert et al found no evidence that non-pharmacological interventions had been attempted, either before or in combination with pharmacological prophylaxis in any patient. Whilst it is reassuring that prevention is used in some patients, and that no cases of DVT occurred, these findings raise a number of important issues for psychiatric practice. Most strikingly, they suggest that patients receiving seclusion are not receiving the least invasive interventions, and that the majority receive no preventive intervention whatsoever. Given that in this study, and in general, most seclusions are against the patients' will, this is exposing the patient to an iatrogenic and preventable risk to which they have not consented. In view of this it is clearly of paramount importance that both the risks associated with them and the invasiveness of the procedure are minimised. Risk assessment should be the first step, factoring in the degree of restraint and immobility of the patients and the known risk factors discussed above. Further work is clearly needed to define specific risks in this group of patients and appropriate measures to combat it, although the data reported by Hert et al indicate that the use of non-pharmacological interventions needs to be increased. There is likely to be considerable variation in practice between different units and units should be aware of their own protocols and audit their usage probably through a local thrombosis committee. It is also important to offer patients and/or their families or carers verbal and written information on the signs and symptoms of deep vein thrombosis and pulmonary embolism, and the importance of seeking medical help and who to contact if DVT, PE or another adverse event is suspected.

The message is that further research is needed. However, at the present time it seems appropriate to individually risk assess all admitted psychiatric patients for VTE and bleeding risk and consider physical restraint and the use of antipsychotic therapy as additional risk factors mandating prophylaxis.

Gerry Stansby, Simon Noble, Oliver Howes. 
References.

1. Department of Health. Report of the independent expert working group on the prevention of venous thromboembolism (VTE) in hospitalised patients. 2007. www.dh.gov.uk/prod consum $\mathrm{dh} /$ groups/dh digitalassets/documents/digitalasset $\angle$ dh 073950.pdf.

2. Hunt BJ. Awareness and politics of venous thromboembolism in the United Kingdom. Arterioscler Thromb Vasc Biol 2008;28:398-9.

3. NICE clinical guideline 92. Reducing the risk of venous thromboembolism (deep vein thrombosis and pulmonary embolism) in patients admitted to hospital. http://guidance.nice.org.uk/CG92

4. Hill J, Treasure T; National Clinical Guideline Centre for Acute and Chronic Conditions. Reducing the risk of venous thromboembolism in patients admitted to hospital: summary of NICE guidance. BMJ. 2010 Jan 27;340

5. Using the Commissioning for Quality and Innovation (CQUIN) payment framework - an addendum to the 2008 policy guidance for 2010/11. Department of Health. http://www.dh.gov.uk/dr_consum_dh/groups/dh_digitalassets/documents/digitala sset/dh 110431.pdf

6. Department of Health. Risk assessment for venous thromboembolism (VTE). www.dh.gov.uk/prod_consum_dh/groups/dh_digitalassets/@dh/@en/documents Ldigitalasset/dh 088216.pdf.

7. Dietrich-Muszalska A, Rabe-Jabłońska J, Olas B. The effects of the second generation antipsychotics and a typical neuroleptic on collagen-induced platelet aggregation in vitro. World J Biol Psychiatry. 2010 Mar;11(2 Pt 2):293-9.

8. Thomassen R, Vandenbroucke JP, Rosendaal FR. Antipsychotic medication and venous thrombosis. Br J Psychiatry. 2001 Jul;179:63-6.

9. Singh G, Wahi S. Pulmonary embolism in the ECT patient: a case report and discussion. Gen Hosp Psychiatry. 2008 Jan-Feb;30(1):87-9.

10. Dickson BC, Pollanen MS. Fatal thromboembolic disease: a risk in physically restrained psychiatric patients. J Forensic Leg Med. 2009 Jul;16(5):284-6.

11. Laursen SB, Jensen TN, Bolwig T, Olsen NV. Deep venous thrombosis and pulmonary embolism following physical restraint. Acta Psychiatr Scand. 2005 Apr;111(4):324-7

12. Hewer W, Kauder E, Vierling P. Fatal pulmonary embolism following antipsychotic treatment and physical restraint. Pharmacopsychiatry. 2009 Sep;42(5):206-8. 